\title{
Kesadaran dan Perilaku Plagiarisme dikalangan Mahasiswa (Studi pada Mahasiswa Fakultas Ekonomi Jurusan Akuntansi Universitas Semarang)
}

\author{
Febrina Nafasati Prihantini \\ Dian Indudewi
}

\begin{abstract}
ABSTRAK
Praktek copy paste merupakan sesuatu yang sering dilakukan mahasiswa dalam menjalani perkuliahan mereka, dimana tindakan copy paste merupakan bagian dari plagisrisme. Penelitian ini bertujuan untuk mengetahui bagaimana persepsi mahasiswa mengenai tindakan plagiarism, seberapa sering mereka melakukan tindakan plagiarism dan alasan apa yang menyebabkan mereka melakukan tindakan plagiarisme.

Metode yang digunakan adalah metode kualitatif dengan model fenomenologi (phenomenology). Dimana jumlah responden yang digunakan dalam penelitian ini adalah 11 mahasiswa yang sedang menyelesaikan tugas akhir skripsi.

Hasil penelitian menunjukkan bahwa mahasiswa memiliki persepsi yang sama mengenai tindakan plagiarisme akan tetapi mereka terkadang tetap melakukannya dikarenakan adanya halhal yang mendorong mereka untuk melakukannya seperti batas waktu menyelesaikan tugas, Hal tersebut seperti batas waktu menumpuk tugas, mahasiswa tidak cukup menemukan bahan untuk menyelesaikan tugas mereka, dosen yang tidak mempermasalahakan mengenai plagiarisme dan sememberikan atau mencantumkan kutipan.
\end{abstract}

Kata Kunci : plagiarisme, persepsi

\section{PENDAHULUAN}

Tugas merupakan salah satu bentuk komponen dari penilaian dosen kepada mahasiswa.. Dikarenakan tugas merupakan komponen dari penilaian, mahasiswa berusaha untuk dapat menyelesaikan semua tugas yang dibebankan kepadanya agar dapat memperoleh nilai yang memuaskan diakhir perkuliahan. Berbagai cara dilakukan oleh mahasiswa untuk dapat menyelesaikan tugas tersebut, salah satunya adalah dengan melakukan copy paste yaitu menyalin tugas dari salah seorang rekan atau teman mereka. Copy paste atau menyalin adalah kata yang sering kita dengar. Praktek copy paste merupakan sesuatu yang sering dilakukan oleh mahasiswa dalam menjalani perkuliahan mereka. Sehingga tidaklah mengherankan pada saat tugas tersebut dikumpulkan maka kita sering menjumpai banyak kemiripan jawaban antara mahasiswa satu dengan mahasiswa yang lainnya dimana praktek copy paste adalah merupakan bagian dari plagiarism.

Hal ini diperparah dengan adanya fasilitas internet yang memiliki kemudahan dalam mengakses segala informasi yang dibutuhkan oleh mahasiswa, yang memperbesar peluang mahasiswa untuk melakukan plagiarisme. Mahasiswa umumnya memiliki kesalahpahaman bahwa internet adalah sumber bebas untuk mengumpulkan informasi tanpa mengakui penulisnya (Willems, 2003) dalam Yemisi, 2012) . Sehingga mereka merasa tidak perlu menuliskan sumber 
kutipan dalam tugas mereka. Yemisi (2012) meyebutkan ada beberapa alasan terjadinya tindakan plagiarisme yaitu kurangnya pengetahuan tentang aturan mengutip dan referensi (JISC,2005), ketidakmampuan untuk mengatasi beban kerja dan ketrampilan manajemen waktu yang buruk (James, McInnis dan Delin, 2002), tekanan untuk mendapatkan prestasi yang bagus (Introna,et al.2003), kurangnya motivasi untuk berprestasi, kemalasan dan faktor budaya (Handa dan Power, 2005).

Perguruan tinggi sebagai lembaga pendidikan bertujuan menghasilkan pemikir yang kreatif dan orisinil yang dapat memberikan kontribusi yang bermanfaat bagi masyarakat (Yemisi, 2012). Dengan banyaknya tindakan (perilaku) plagiarisme yang dilakukan mahasiswa memberikan dampak berkurangnya nilai intergritas akademik dan memberikan efek yang negatife pula kepada mahasiswa lain yang tidak melakukan tindakan (perilaku) plagiarisme (JISC, 2005). Oleh karena itu perlu diketahui mengenai pemahaman mahasiswa mengenai plagiarisme dan faktor-faktor apa saja yang mendorong adanya perilaku plagiarisme sebagai usaha untuk memerangi plagiarisme dikalangan mahasiswa. Berdasarkan latar belakang diatas maka pertanyaan penelitian adalah Apakah mahasiswa Fakultas Ekonomi Jurusan Akuntansi Universitas Semarang memahami perilaku intelektual atau perilaku akademik yang merupakan perilaku plagiarism, bagaiaman bentuk dari tindakan plagiarism serta alasan apa yang menjadi penyebab mahasiswa jurusan akuntansi melakukan tindakan plagiarisme ?. Adapun tujuan penelitian ini adalah untuk mengetahui mengenai pemahaman atau persepsi mahasiswa mengenai perilaku plagiarisme dan faktor - faktor apa saja yang mendorong perilaku plagiarisme dikalangan mahasiswa.

\section{TINJAUAN PUSTAKA}

Teori pertukaran sosial dari George Homans (1961) adalah salah satu teori yang berlandaskan perspektif perilaku sosial. Teori pertukaran Homans bertumpu pada asumsi bahwa orang terlibat dalam perilaku untuk memperoleh ganjaran atau menghindari hukuman. Menurut Homans (1961), teori ini "membayangkan perilaku sosial sebagai pertukaran aktivitas, nyata atau tak nyata, dan kurang lebih sebagai pertukaran hadiah atau biaya, sekurang-kurangnya antara dua orang." (Homans , 1961 dalam Ritzer, 2011).

Ada beberapa proposisi dari teori Homans dalam Ritzer dan Goodman (2011), yaitu: Proposisi sukses, Proposisi stimulus, Proposisi nilai, Proposisi deprivasi satiasi, Proposisi persetujuan agresi dan Proposisi rasionalitas.

Homans (1961) yang dikutip oleh Candra (2013) menggunakan dua konsep dari B.F Skinner untuk menganalisis perilaku manusia dalam pertukaran sosial. Homans tertarik dengan eksperimen Skinner terhadap sebuah hewan yaitu pigeon (burung dara) yang berada dalam sangkar, burung dara tersebut diberi butiran padi sebagai penguat (reinforcement) tindakannya. Dalam eksperimen tersebut, Homans (1961) yang dikutip oleh Candra (2013) menggambarkan bahwa burung dara melakukan suatu tindakan berdasarkan rangsangan yang diberikan kepadanya. Ketika dia diberi rangsangan berupa makanan, dia akan melakukan tindakan yang positif untuk mendapatkan makanan itu. Ketika ketika burung dara diberi rangsangan berupa siraman air dingin, maka dia akan melakukan tindakan negatif. Rangsangan berupa air dingin tersebut disebutnya sebagai sebuah punishment (hukuman) dimana burung dara tersebut berada dalam aversive condition (kondisi tertekan) yang menyebabkan dia mencari cara untuk keluar dari air dingin tersebut.

Lebih lanjut lagi, Candra (2013) mengutip pernyataan Homas (1961) dalam pembahasan mengenai pertukaran sosial, Homans (1961) menjelaskan bahwa perilaku sosial yang dilihatnya 
dari burung dara tersebut merupakan bentuk perilaku satu arah. Sedangkan, dalam penelitiannya selanjutnya dia mengamati tentang hubungan timbal balik antara dua orang atau lebih yang dikatakannya sebagai bentuk pertukaran sosial. Homans (1961) memberikan contoh antara dua orang yang bekerja dalam satu kantor yang bertukar bantuan dan persetujuan untuk mendapatkan promosi pekerjaan. Berdasarkan pemikiran tersebut, Homans (1961) dalam Candra (2013) mengembangkan beberapa proposisi untuk menjelaskan pertukaran sosial yang terjadi antara dua orang atau lebih yang didasarkan oleh aspek hukuman dan hadiah dimana perilaku individu ditentukan oleh besaran nilai hadiah yang didapatnya.

Menurut Homans (1961) yang dikutip oleh Candra (2013), teori ini "membayangkan perilaku sosial sebagai pertukaran aktivitas, nyata atau tak nyata, dan kurang lebih sebagai pertukaran hadiah atau biaya, sekurang-kurangnya antara dua orang. Dalam Social behaviour: Its Elementary Forms, Homans (1961) dalam Candra (2013) menyatakan bahwa teori pertukarannya berasal dari psikologi perilaku dan ilmu ekonomi dasar (teori pilihan rasional).

Menurut Peraturan Menteri Pendidikan RI Nomor 17 Tahun 2010 dikatakan:

"Plagiat adalah perbuatan sengaja atau tidak sengaja dalam memperoleh atau mencoba memperoleh kredit atau nilai untuk suatu karya ilmiah, dengan mengutip sebagian atau seluruh karya dan atau karya ilmiah pihak lain yang diakui sebagai karya ilmiahnya, tanpa menyatakan sumber secara tepat dan memadai"

Dalam Kamus Besar Bahasa Indonesia (2008) disebutkan:

"Plagiat adalah pengambilan karangan (pendapat dan sebagainya) orang lain dan menjadikannya seolah-olah karangan (pendapat) sendiri".

Berdasarkan pengertian diatas dapat disimpulkan bahwa plagiarisme adalah tindakan mengambil karya orang lain secara keseluruhan atau sebagian yang dilakukan baik secara sengaja maupun tidak sengaja.

\section{METODE PENELITIAN}

Penelitian ini menggunakan metode kualitatif dengan model Fenomenologi (phenomenology). Dikarenakan penelitian ini bertujuan ingin mengali lebih dalam mengenai fenomena plagiarisme yang terjadi dikalangan mahasiswa Jurusan Akuntansi Universitas Semarang. Herdiansyah (2010) menyebutkan Fenomenologi (phenomenology) berkaitan dengan suatu fenomena, fenomenologi lebih memfokuskan diri pada konsep suatu fenomena tertentu dan bentuk dari studinya adalah untuk melihat dan memahami arti dari suatu pengalaman individual yang berkaitan dengan suatu fenomena tertentu.

Teknik pemilihan sampel dalam penelitian ini dengan menggunakan purposeful sampling. Purposeful sampling merupakan teknik dalam non-probability sampling yang berdasarkan kepada ciri-ciri yang dimiliki oleh subjek yang dipilih karena ciri-ciri tersebut sesuai dengan tujuan penelitian yang akan dilakukan (Herdiansyah,2010). Responden dalam penelitian ini adalah mahasiswa jurusan Akuntansi Universitas Semarang yang sedang menyelesaikan tugas akhir skripsi. Metode pengumpulan data yang digunakan dalam penelitian ini adalah dengan menggunakan metode wawancara terstuktur.

\section{HASIL PENELITIAN DAN PEMBAHASAN}

Peneliti menggunakan wawancara terstruktur di dalam proses pengumpulan data. Responden yang digunakan dalam penelitian ini adalah mahasiswa Jurusan Akuntansi Universitas Semarang yang sedang menyelesaikan tugas akhir skripsi sebanyak 11 orang mahasiswa. Mahasiswa yang sedang menyelesaiakan tugas akhir adalah mahasiswa yang sudah 7 
atau 8 semester mengikuti perkuliahan sehingga diharapakan mahasiswa semester 7 atau semester 8 telah memiliki persepsi yang baik mengenai arti plagiarisme.

Item wawancara yang digunakan dalam wawancara terstruktur mengacu pada Item pertanyaan yang dikembangkan oleh Yemisi (2012) yang berkaitan dengan plagiarisme terdiri dari bagian pertama mengenai persepsi dan pengertian dari tindakan (perilaku) plagiarisme, bagian kedua mengenai seberapa sering tindakan plagiarisme dilakukan dan bagian ketiga mengenai alasan melakukan plagiarisme.

Persepsi 11 mahasiswa Jurusan Akuntansi Universitas Semarang Universitas Semarang mengenai "Apa yang dimaksud dengan Plagiarisme" semuanya telah memiliki persepsi yang sama bahwa yang dimaksud tindakan plagiarisme adalah menyalin atau mengambil karya orang lain tanpa menyebut sumber kutipannya baik itu menyalin dan mengutip kata demi kata yang berasal dari buku atau artikel (jurnal), mengutip dan menyalin suatu bagian dari dokumen eletronik (internet) tanpa menyebut sumber kutipan, mengambil artikel dari internet yang dianggap sebagai pekerjaan (tugas) mereka (mahasiswa) dan tidak memasukkan sumber kutipan di dalam daftar pustaka.

Akan tetapi 11 mahasiswa Jurusan Akuntansi Universitas Semarang memiliki persepsi yang berbeda apakah menyalin tugas teman dan memasukkan sumber kutipan dalam daftar pustaka dimana tidak ada satupun yang dimasukkan dalam tugas disebut dengan tindakan plagiarisme. Sebagian mahasiwa menyatakan bahwa bila menyalin tugas dari teman sepanjang meminta ijin atau sepengetahuan dari yang bersangkutan maka itu bukan merupakan tindakan plagiarisme. Sedangkan untuk tindakan memasukkan sumber kutipan dalam daftar pustaka dimana tidak ada satupun yang dimasukkan dalam tugas, sebagian besar mahasiswa ragu-ragu untuk menyebutkan bahwa tindakan tersebut merupakan tindakan plagiarism dikarenakan mereka tidak mengutip apapun di dalam tugas mereka. Mahasiswa lebih cenderung mengangap tindakan tersebut sebagai tindakan menipu bukan sebagai tindakan plagiarisme.

11 Responden menyatakan bahwa mereka tidak sering atau kadang-kadang melakukan tindakan plagiarisme. Terkadang mahasiswa dalam menyelesaikan tugasnya menyalin dari teman atau rekan dengan seijinnya dikarenakan mereka mengenal teman atau rekan yang tugasnya mereka salin. Akan tetapi mahasiswa tidak pernah menyalin tugas dari orang lain tanpa seijinnya dikarenakan mereka merasa tidak mengenal orang tersebut. Demikian pula menyalin kata demi kata atau mengutip secara langsung dari buku atau jurnal tanpa menggunakan tanda kutip terkadang dilakukan mahasiswa pada saat mereka membuat tugas dengan alasan lupa. Mahasiswa juga terkadang lupa mengutip dan menyalin suatu bagian dari dokumen elektronik (internet) atau sumber lain tanpa menyebut sumber kutipan dimana mahasiswa akan mencari jawaban untuk tugas mereka di internet jika mereka kesulitan mencari jawaban untuk tugas dari buku. Akan tetapi Mahasiswa Jurusan Akuntansi Universitas Semarang memiliki sikap yang sama bahwa mereka tidak pernah membuatkan (membeli) tugas dari seseorang.

Alasan mahasiswa Jurusan Akuntansi Universitas Semarang melakukan tindakan plagiarisme dikarenakan mereka tidak tahu bagaimana mencari sumber kutipan untuk kata atau kalimat yang mereka kutip dan tidak tahu bagaimana mengutip sumber yang berasal dari internet dan sumber lain. Selain itu ada banyak bahan yang mahasiswa butuhkan tersedia gratis di internet dikarenakan mahasiswa tidak cukup menemukan bahan untuk menyelesaikan tugas mereka. Dan batas waktu (deadline) menyelesaikan tugas juga menjadi alasan mahasiswa melakukan plagiarisme. Ditambah dengan dosen tidak mempermasalahkan ketika mahasiswa melakukan tindakan plagiarism didalam menyelesaiakan tugas mereka. 
Berdasarkan teori pertukaran sosial Homans yang terjadi antara dua orang atau lebih yang didasarkan oleh aspek hukuman dan hadiah dimana perilaku individu ditentukan oleh besaran nilai hadiah yang didapatnya (Candra, 2013). Plagiarisme yang dilakukan oleh para mahasiswa jurusan Akuntansi Universitas Semarang jika dikaitkan dengan teori pertukaran sosial dari Homans, maka plagiarisme adalah suatu tindakan yang dilakukan oleh mahasiswa dimana mereka ingin mendapatkan hadiah dari dosen berupa nilai yang baik dikarenakan sudah mengumpulkan tugasnya dengan tepat waktu dan berharap tidak mendapatkan hukuman.

Beberapa bukti dari asumsi tersebut bisa dilihat dari pendapatan yang dikemukakan oleh para mahasiswa, bahwa mahasiswa kadang-kadang melakukan plagiarism jika dalam kondisi yang sudah terdesak seperti batas waktu untuk menumpuk tugas sudah dekat dan mereka tidak menemukan sumber atau bahan dari buku, sehingga mereka terpaksa melakukan plagiarisme dengan cara mencari dari internet atau meminjam tugas dari teman yang mereka kenal. Dikarenakan mahasiswa dikejar waktu harus mengumpulkan tugas maka mereka terkadang lupa memasukkan sumber kutipan atau menuliskan sumber kutipan didalam tugas mereka.

Berdasarkan keenam proposisi yang disampaikan oleh Homans (1961), ada dua proposisi yang cocok untuk digunakan dalam menganalisis plagiarisme mahasiswa jurusan akuntansi , yaitu proposisi sukses dan pendorong. Berikut ini adalah penjelasannya:

1. Proposisi Sukses

Setiap mahasiswa pada dasarnya mempunyai keinginan untuk memperoleh kesuksesan melalu pendidikan tinggi yang mereka tempuh. Berbagai cara dapat mereka lakukan untuk meraih kesuksesan tersebut, seperti belajar dengan giat sebelum ulangan, selalu aktif dalam kelas dan mengerjakan tugas-tugas yang diberikan oleh dosen (Candra,2013). Akan tetapi untuk mencapai hal tersebut terkadang mahasiswa melakukan tindakan yang bertentangan dengan etika akademis, seperti menyalin tugas dari teman atau rekan atau mencari jawaban dari internet.

2. Proposisi Pendorong

Pada saat mahasiswa melakukan plagiarism ada hal-hal yang mendorong mahasiswa melakukannya. Seperti batas waktu untuk mengumpulkan tugas mereka, atau ketika mereka kesulitan mencari bahan atau sumber untuk tugas mereka dan dosen tidak mempermasalahkan apakah tugas yang mereka kumpulkan merupakan hasil dari plagiarisme.

\section{PENUTUP}

Teori Pertukaran sosial antara mahasiswa dan dosen berdasarkan adanya reward (hadiah) dan punishment (hukuman). Plagiarisme mahasiswa adalah salah satu tindakan yang berdasarkan konsep hadiah dan hukuman, dikarenakan dalam mengerjakan tugas mahasiswa melakukan plagiarisme agar mendapatkan nilai yang baik sebagai hadiah dan menghindari kemarahan dosen sebagai hukuman.

Mahasiswa Jurusan Akuntansi Universitas Semarang memiliki persepsi yang sama mengenai plagiarism yaitu tindakan menyalin atau mengambil karya orang lain tanpa menyebut sumber kutipannya. Walaupun mahasiswa telah mengetahui pengertian dari tindakan plagiarisme tetapi mahasiswa terkadang tetap melakukan tindakan tersebut, dimana ada hal-hal yang mendorong mahasiswa terkadang melakukan tindakan plagiarism. Hal tersebut seperti batas waktu menumpuk tugas, mahasiswa tidak cukup menemukan bahan untuk menyelesaikan tugas mereka, dosen yang tidak mempermasalahakan mengenai plagiarisme dan ketidaktahuan 
mahasiswa mengenai tata cara penulisan kutipan ataupun dengan alasan lupa memberikan atau mencantumkan kutipan.

Mahasiswa Jurusan Akuntansi memiliki perasaaan bersalah atau berdosa ketika mereka melakukan tindakan plagiarism, walaupun perasaan itu baru muncul ketika mereka telah mengumpulkan tugas. Pada saat posisi mereka terdesak, mereka mengatakan cenderung mengabaikan perasaan bersalah tersebut dikarenakan mereka tidak ingin mendapatkan hukuman karena tidak mengumpulkan tugas. Akan tetapi sebagian mahasiswa mengatakan bahwa bila mereka menyalin tugas dari teman maka tidak ada rasa bersalah dikarenakan mereka menanggap bahwa menyalin tugas dari teman sepanjang ijin dari yang bersangkutan itu bukanlah merupakan suatu tindakan plagiarism.

Adapun keterbatasan penelitian ini adalah wawancara terhadap responden hanya dilakukan satu kali sehingga wawancara tidak dilakukan secara insentif untuk memperoleh jawaban yang lebih mendalam dan wawancara dilakukan dengan wawancara terstruktur pertanyaan yang diajukan hanya terbatas pada item yang sudah ada tidak bisa dikembangkan lagi. Sehingga untuk penelitian selanjutnya agar wawancara dilakukan lebih satu kali sehingga diperoleh jawaban yang konsisten mengenai item pertanyaan yang diajukan dan lebih baik wawancara diajukan juga secara tidak terstruktur sehingga bisa dimungkin memperoleh variasi jawaban yang lebih banyak.

\section{Daftar Pustaka}

Handa, N. and Power, C. (2005). Land and Discover! A Case Study Investigating the Cultural Context of Plagiarism. Journal of University Teaching and Learning Practice, 2 (3) 64-84.

Herdiansyah (2010). Metodologi Penelitian Kualitatif Untuk Ilmu-Ilmu Sosial. Salemba Humanika.

Hendrawan Soetanto (2014). Plagiarisme Akademik. Makalah.ppikid.ub.ac.id

Introna, L., Hayes, N., Blair, L. and Wood, E. (2003). Cultural Attitudes Towards Plagiarism: Developing a Better Understanding of the Needs of Students from Diverse Backgrounds Relating to Issues of Plagiarism. Available: http://online.northumbria.ac.uk/faculties/art/information studies/Imri/Jiscpas/docs/external/lancsplagiarismreport.pdf (Accessed 21 November 2009).

James, R., McInnis, C. and Devlin, M. (2002). N Minimising Plagiarism. Assessing Learning in Australian Universities. Available: http://www.cshe.unimelb.edu.au/assessinglearning/03/plagMain.html (Accessed 2 March 2010). 
JISC (2005). Deterring, Detecting and Dealing with Student Plagiarism Available: http://www.jisc.ac.uk/media/documents/publications/plagiarismbp.pdf (Accessed 6 January 2010).

Rachmatul Candra Ariani (2013), Opini Mahasiswa Ilmu Sosial dan Ilmu Politik Terhadap Plagiarisme. Media Komunitas. Vol 2 No.1.

Ritzer, George dan Goodman, Douglas J, 2011. Teori Sosiologi Modern. Jakarta:Kencana.

Kamus Besar Bahasa Indonesia.2008

Peraturan Menteri Pendidikan RI No. 17 tahun 2010

Utorodewo, Felicia, dkk. 2007. "Bahasa Indonesia: Sebuah Pengantar Penulisan Ilmiah". Jakarta: Lembaga Penerbit FEUI.

Willems, H. (2003). Plagiarism at your School Library. Library Media Connection, 38- 31.

Yemisi T. Babalola. 2012. "Awareness and incidence of plagiarism among undergraduates in a Nigerian private Univerity". African Journal of Library, Archies and Information Science. 22.1 (Apr. 2012): p53.

Yin, R.K. 1994. Case study research: Design and methods. 2nd Edition. Thousand Oaks, CA: Sage Publications.

Zalnur Muhammad. "Plagiarisme dikalangan Mahasiswa dalam membuat tugas-tugas perkuliahan pada Fakultas Tarbiyah IAIN Imam Bonjol Padang. Jurnal Al-Ta'lim. Jilid 1. Nomor 1. Februari 2012. Hlm 55-56. 
Jurnal Dinamika Sosial Budaya, Volume 18, Nomor 1, Juni 2016 